\title{
The Leadership Style of Headmaster in Guiding the Character of Teachers in the Public Senior High School 2 Limboto
}

\author{
Hamzah B. Uno, Keysar Panjaitan, Nina Lamatenggo, Kasim Yahiji
}

\begin{abstract}
This research aims to (1) discover the democratic leadership style in guiding the characters of teachers at Public Senior High School 2 Limboto, (2) to know the autocratic leadership style in guiding the characters of teachers at Public Senior High School 2 Limboto, (3) to know the paternalistic leadership style in guiding the characters of teachers at Public Senior High School 2 Limboto, (4) to know the laissez-faire leadership style in guiding the characters of teachers at Public Senior High School 2 Limboto. This research was an explanatory research and the method used was survey method, whereas the number of population and the sample was 34 people. Then, from the research was obtained some results, they were: (1) the implementation of democratic leadership style in guiding the characters of teacher, it was obtained the very high category that was the average score 3,29, (2) the implementation of autocratic leadership style in guiding the characters of teacher and obtained the average score 3.00 with high category, (3) the implementation of paternalistic leadership style in guiding the characters of teacher, it was obtained the average score 3,23 included the very high category, and (4) the implementation of laissez-faire leadership style in guiding the characters of teacher, it was obtained the average score 1,32 and belonged to low category.
\end{abstract}

Keywords-Leadership Style, Guidance, Character of teachers.

\section{INTRODUCTION}

One of the problems being faced by our nation is about character. One alternative offered to solve the character problem is by conducting a good education. Education is considered as an alternative which has preventive characteristic because education establish the better new generation of nation. As an alternative which has preventive characteristic, education is expected to develop and minimize the cause of various problems of culture and nation's character. It should be admitted that the result of education can't be instantly seen, but it has a strong resistance and effect among the societies.

Teacher is an education doer who has strategic position to realize the purposes of character building as mandated by Pancasila and also in the preambule (opening) of Indonesia's basic constitution 1945 and it is more emphasized with the constitution number 20 Year 2003 about the National Education System where the function and the purpose of national education are " the national education has the function to develop and form the character and the good civilization of the nation, which has purpose to develop the students' potency so they can become faithful human and obey the God, having the good characters, healthy, having knowledge, capable, creative, independent, and becoming democratic and responsible citizens".

Teacher is the first people in the practice of education who should become the pattern for his students. Teaching, educating, and training are the main duty of teacher and becoming a strategic position in educating characterized students. As mentioned in the Regulation of Ministry of the Utilizing of Civil Servants and Reformation Number 16 Year 2009 about the Teachers' Functional Position and Its Credit Number, it is explained that the primary duties of teachers are to educate, teach, guide, direct, train, assess, and evaluate the students in the early age education in some categories such as formal education, basic education, and middle age education and also the additional duty which is relevant with the function of school/madrasah.

Character according to Language Centre National Education Department is the heart, soul, personality, manner, behaviour, characteristic, temperament, and mind. Whereas, according to the Ministry of National Education (2010:3), character is a characteristic, behaviour, or someone's personality which is formed from the internalisation result of various virtues which are believed and were used as the background of the way to see, think, behave, and act.

The leadership of headmaster is the key to the success or failure of a school organization, therefore the leadership style used by the headmaster is one of the factors in creating a conducive school climate and also the good school performance. The school climate is closely related to the leadership style of the headmaster, because the headmaster is the highest policy maker in the school. The accuracy of the headmaster in choosing a leadership style will lead to the achievement of school goals. As Mulyasa (2012: 5) states that the success or failure of 
education and learning in school is strongly influenced by the ability of headmaster in managing each component of the school (who is behind the school).

Based on the results of observations and preliminary interviews with the headmaster, the author can conclude that the headmaster's leadership style in fostering teacher character uses 4 (four) leadership styles, they are: 1) democratic leadership style, 2) autocratic leadership style, 3) paternalistic leadership style and laissez faire leadership style. Of the four leadership styles, the author was interested in conducting research in order to study further by using questionnaires distributed to teachers and deepened through interviews with the school headmasters, vice headmaster, teachers and administration staffs. This thing was purposed in order to describe the leadership style of the headmaster in fostering the teacher's character which consisted of independent character, creative character, discipline character and hard work character. This thing is the background that cause the author is very interested in conducting research with the title "Principal Leadership Style in Fostering Teachers' Character in Public Senior High School 2 Limboto".

\section{LITERATUR REVIEW}

\section{The Essence of Headmaster's Leadership Style}

Leadership according to Thoha (2010: 9) means

that: "Leadership is the ability to influence people to be directed towards the achieving of organization's goals". According to Wahyudi (2009: 120), it can be interpreted as: "A person's ability to move, direct, and influence the mindset and workings of each member, in order to be independent in working. While according to the National Education Department (1999) in Syafaruddin (2010: 88) states, "Leadership is the way or effort of the headmaster in influencing, encouraging, guiding, directing, and mobilizing teachers, staffs, students, parents, and other parties involved in working or participate in achieving the goals ".

The definition above is supported by the opinion of Soekarto Indrafachrudi in his book Bagaimana memimpin Sekolah yang Efektif (How to lead an Effective School) (2006: 3), giving the meaning of leadership as follows: "Leadership is an activity in guiding groups in such a way that the group's goals are achieved". Whereas according to Masaong (2011: 161) leadership functions as an action taken by the headmaster in an effort to mobilize teachers to do something to realize the formulated work program". This is reinforced by Husaini Usman (2009: 280), "Leadership is a deep relationship of a leader, to influence other people to establish a conscious cooperation in the relationship of the tasks that should be done".
The headmaster's leadership process is related to the leadership style which is used. From various headmaster's leadership styles, situational style tends to be more flexible in the school operational condition. The situational leadership style departs from the point that there is no best leadership style of the headmaster that can be used, but depends on the situation and condition of the school. These situations and conditions include the level of maturity of teachers and staffs, which can be seen from two dimensions: the dimension of ability (awareness and understanding) and the dimension of willingness (responsibility, care and commitment).

Furthermore, according to Sondang Siagian (2006: 74), "The leadership style applied by a leader is various". This is caused by differences in motivation that a leader has in conducting his duties. According to Sondang Siagian (2006: 254), the leadership style consists of: 1) Democratic leadership style, 2) Autocratic leadership style, 3) Paternalistic leadership style, and 4) Laissez-Faire leadership style.

\section{The Character of Teachers}

To know the meaning of character, it can be seen from two sides, those are from the linguistic side and the terminology side. According to language (etymologically) the term character originates from the Latin language kharakter, kharassaein, and kharax. In the Greek character, it is originated from the word charassein, which means to sharpen and to deepen. In English, it is called as character and in Indonesian are commonly known with the term karakter (Gunawan, 2012: 1). Meanwhile in the Indonesian Language Dictionary, the Ministry of National Education Language Center states that character means mental, moral or character traits that distinguish a person from others, or means innate, heart, soul, personality, character, behavior, personality, character, character, temperament, character. So the term character means having character, having personality, and behaving. Individuals who have good character to excel are someone who tries to do the best things to the God, himself, others, environment, nation, and country and the international world in general by optimizing his potential (knowledge) and accompanied by the awareness, emotion and his motivation (feeling).

According to the General Directory Ministry of National Education (2011: 8) Character is behavior based on values based on the religious norm, culture, law / constitution, custom, and aesthetic. The constitution Number 20 Year 2003 Article 3 of the National Education System, which states that national education functions to develop capabilities and form the national character and civilization to develop potential students to become human beings who are knowledgeable, capable, creative, 
independent and become citizens who are democratic and responsible.

According to the Constitution of Indonesia Number 14 Year 2005 about Teacher and Lecturer, in chapter 1 article 1 states that: "Teachers are professional educators with the main task to educate, teach, guide, direct, train, assess and evaluate students in early childhood education formal education, basic education, and secondary education."

According to Koswara Deni and Halimah (2008: 29) "Teachers are all people who are responsible for the education of students, both individually and classically, both in school and outside school, who must master various competencies such as pedagogy, personality, social and profession".

Based on the description above, the teacher's character is the psychological, moral or ethical characteristics in conducting the task of educating, teaching, guiding, directing, training, assessing and evaluating students based on the values based on the religious norm, cultural, legal / constitutional, custom, and aesthetic.

\section{RESEARCH METHOD}

This research was conducted at the Public Senior High School 2 Limboto. The study was conducted for 3 (three) months, started from March to June 2016 which included observation, preparation, data collection through the analysis of document, observation, interview and questionnaire to the preparation of research reports. This research was explanatory research. The study used a descriptive design that aimed to describe the leadership style of the headmaster in fostering teachers' character in Public Senior High School 2 Limboto based on the characteristic of the studied object. The population in this study was the all characteristics, objects and other objects related to the leadership style of the headmaster in fostering the character of the teachers in Limboto 2 High School. The respondents used were 34 teachers (including vice headmaster, treasurer and administrative staff).

The data collection technique that will be used to support problem solving are, as follows: a) questionnaire, b) interview, c) documentation. The data obtained will be analyzed using descriptive statistical analysis then data that has been analyzed quantitatively are deepened or strengthened by the results of interviews.

\section{RESULTS}

The results of the research on the democratic leadership style of the head of Public Senior High School 2 Limboto were measured by questionnaires and confirmed by the results of interviews showed that character building responsibility through delegation, from the tendency of respondents' answers, 17 respondents or $50.00 \%$ answered with category never. The creativity character fostering through providing support, from the tendency of respondents, 16 respondents or $47.06 \%$ answered with the category always. The development of character discipline through sanctions, from the tendency of respondents, 18 respondents or $52.9 \%$ answered with the category always. The hard work character fostering through the awarding, from the tendency of respondents, 11 respondents or $32.35 \%$ answered with the category ever.

The autocratic leadership style of the headmaster of Public Senior High School 2 Limboto was measured by using a questionnaire and confirmed by the results of interviews, showed that the guidance of the independence character through delegation, from the tendency of respondents' answers, 14 respondents or $41.18 \%$ answered with the category always. The creativity character fostering through the providing of support, from the tendency of respondents, 14 respondents or $41.18 \%$ to respond with category never. The development of character discipline through the sanction, from the tendency of respondents, 34 respondents or $100 \%$ to respond with category never. The hard work character fostering through the awarding, from the tendency of respondents, 29 respondents or $85.29 \%$ to respond with category never.

The paternalistic leadership style of headmaster of the Public Senior High School 2 Limboto which was measured by using questionnaires and confirmed by the results of interviews showed that the guidance of the independence character through delegation, from the tendency of respondents' answers, 12 respondents or $35.29 \%$ answered with the always category and 12 respondents or $35.29 \%$ answer with frequent categories. The creative character fostering through the providing of support, from the tendency of respondents, 16 respondents or $47.06 \%$ answered with the category always. The development of character discipline through the giving of sanction, from the tendency of respondents, 30 respondents or $88.24 \%$ to respond with category never. The hard-working character fostering through the awarding, from the tendency of respondents, 18 respondents or $52.94 \%$ answered with category never.

The laissez-faire leadership style of Public Senior High School 2 Limboto was measured by using a questionnaire and confirmed by the results of interviews, showed that the guidance of the character of the independence through delegation, from the tendency of the respondents' answers, 34 respondents or $100 \%$ answered with category never. The creative character fostering through the giving of support, from the tendency of respondents, 31 respondents or $91.18 \%$ respond with 
category never. The development of character discipline through the giving of sanction, from the tendency of respondents, 24 respondents or $70.59 \%$ answered with category never. The hard work character fostering through the awarding, from the tendency of respondents, 30 respondents or $88.24 \%$ respond with category never.

\section{DISCUSSION}

For the data processing in the study used the Weighted Means Score (WMS) formula by calculating the frequency of respondents who chose the alternative answer, then multiplied by the weight of the alternative value itself. Followed by calculating the average value ( $\bar{x}$ ) for each item statement in the questionnaire, using the Weighted Means Score (WMS) formula and matching the average with the frequency table calculated by WMS as contained in the previous chapter.

Then, it will be presented in the result of research data processing using the WMS calculation technique on the answers of 34 respondents to the statements contained in the questionnaire related to the headmaster's leadership style in fostering teachers' character in Public Senior High School 2 Limboto, Gorontalo.

\section{Democratic Leadership Style}

The highest average score in implementing a democratic style is the development of discipline character with a score of 3.29 compared to fostering creative character with a score of 3.24 . It means that the democratic leadership style of the headmaster of Public High School 2 Limboto in fostering teacher character is focused on the character of discipline and then the creative character and subsequently the character of hard work and independence.

The results of the processing of the instruments were strengthened and deepened by some interviews conducted by the researcher with several informants, they were: the headmaster, the vice headmaster, teachers and administration staffs. From the results of interviews with one of the teachers, information was obtained that the headmaster was very focused on the discipline of the teacher, the headmaster was very unhappy if the lesson time took place there were classes that did not study while the teacher was only on the teacher board to complete other work. In line with one of the deputy principals, it was revealed that the principal often said whatever work was done if there were teaching hours so leave the job and go to class to fulfill the obligations as a teacher. The results of interviews with the headmaster of Public Senior High School 2 Limboto 2 justified the statement above because according to him that the root of all problems was the disciplinary problems such as the time discipline, work discipline, discipline in dress or discipline in obeying all rules and norms as a teacher.
The results of the interview above are reinforced by Siagian (in Sutrisno, 2009: 86), a good form of discipline will be reflected in the atmosphere in the school organization, they were: (1) the high teacher awareness towards achieving the school's vision and mission, (2) the high enthusiasm, work passion and initiative of the teachers in teaching, (3) the great sense of responsibility of the teacher to conduct the task as well as possible, (4) the development of a sense of belonging and a high sense of solidarity among teachers, and (5) increasing work efficiency and productivity . Furthermore, emphasized by Indrafachrudi (2006: 17) one of the characteristics of democratic style is the high discipline.

\section{Autocratic Leadership Style}

The highest average score in the application of autocratic leadership style is independent character guidance with a score of 3.00 compared to the guidance creative characters with a score of 2.06 . It means that the autocratic leadership style of the headmaster of Public Senior High School 2 Limboto in fostering teachers' character is emphasized on the character of independence, creative character and furthermore the character of hard work and discipline.

The results of processing of the instruments were strengthened and deepened by the interviews conducted by the researcher with several informants, they were: the headmaster, the vice headmaster, teachers and administration staffs. From the results of interviews with a teacher, the information obtained that one form of strict supervision conducted by the headmaster was the presence of CCTV cameras throughout the classroom, which were monitored directly from the headmaster's room. Meanwhile, according to the vice headmaster, information was obtained that in Public Senior High School 2 Limboto, the teachers had been given facilities to support their respective duties and functions. Therefore the headmaster often reminds them not to interfere with each other's tasks, they should work according to their duties.

The description above is more emphasized by the headmaster from the interviews obtained information that the main purpose of CCTV camera installed in all classrooms is to monitor and supervise directly the independence of teachers in the learning process in the classroom.

Based on the description above, it can be concluded that the headmaster of Public Senior High School 2 Limboto in fostering the character of independence uses the autocratic leadership style by delegating responsibility with the close supervision. This is reinforced by the opinion of Siagian (in Hikmat, 2009: 254) one of the characteristics of the style of autocracy is 
Monitoring / supervision of the implementation of tasks by subordinates conducted strictly, so that tasks can be accomplished.

\section{Paternalistic Leadership Style}

The highest average score in implementing the externalistic style is the guidance of the creative character with a score of 3.23 compared to independent character guidance with a score of 2.91. It means that the paternalistic leadership style of headmaster of Public Senior High School 2 Limboto in fostering the teacher's character is focused on the creative character, independent character and subsequently the character of hard work and character of discipline.

The results of the processing of the instruments were strengthened and deepened by interviews between researcher and several informants, they were: the headmaster, the vice headmaster, teachers and administration staffs. From the results of interviews with a teacher, information was obtained that the principal always provided motivation to the teachers so that creativity in learning was developed. As a manifestation of the principal's support for teachers' creativity, all facilities or needs will be provided by the school as long as the budget is available for this purpose. This is similar to that expressed by the deputy headmaster of the public relations sector, stating that the principal has never obstructed the desire of teachers to be creative in learning even if possible, all of his needs will be met to realize his creativity.

This was emphasized more by the headmaster who stated that one of the conditions for achieving learning objectives if the teacher was able to choose and determine the right media which is suitable with the material, but often the media was not available or damaged. With that condition, of course teachers' creativity is expected, but how can the teacher be creative if the needs have to be provided by themselves, therefore the school strives to hold all the needs for the creation of teachers' creativity in the learning process

Based on the description above, it can be concluded that the headmaster of Public High School 2 Limboto in fostering the character of creativity uses a paternalistic leadership style by preparing everything needed to develop teachers' creativity. This is reinforced by Siagian's opinion (in Hikmat, 2009: 254) that paternalistic leadership style always considers subordinates as human beings who are not yet mature, or their own children who need to be developed, fulfill all their needs and protect his/her subordinates.

\section{Laissez-Faire Leadership Style}

The highest average score in the implementation of laissez-faire style is the development of disciplinary characters with a score of 1.32 compared to the guidance of hard working character with a score of 1.12. It means that the laissez-faire leadership style of headmaster of Public Senior High School in fostering teacher character is emphasized on the character of discipline, character of hard work and subsequently creative character and independent character.

The results of the processing of the instruments were strengthened and deepened by interviews conducted between researcher and several informants, the informants were the headmaster, the vice headmaster, teachers and administration staffs. From the results of interviews conducted with a teacher, information was obtained that the headmaster had never given sanctions when teachers broke the disciplinary rules. This was confirmed by the headmaster that as a human being who has a heart and feelings, of course it is hard to give sanctions to teachers who arrive late because of the accidental factors.

\section{CONCLUSION}

Based on data analysis using the Weighted Means Score (WMS) technique about the headmaster's leadership style in fostering teachers' character in Public Senior High School 2 Limboto. Then, it can be concluded that the implementation of democratic leadership styles in fostering teachers' character, the highest average score was obtained by disciplinary character development with a score of 3.29 including the category always. The implementation of the autocratic leadership style in fostering the character of the teacher, the highest average score was obtained by fostering independent characters with a score of 3.00 including the category often. The implementation of the paternalistic leadership style in fostering the character of the teacher, obtained the highest average score was the guidance of creative characters with a score of 3.23 including the category always. The implementation of laissez-faire leadership style in fostering the character of the teacher, obtained the highest average score was disciplinary character development with a score of 1.32 including the category ever.

Based on the conclusion above, the following research implications are stated: 1) democratic style, autocratic style, paternalistic style, and laissez-faire style in Public Senior High School 2 Limboto in fostering teachers' character have implications for improving the character of discipline, independent character, creative character and hard work character, 2) the implementation of the appropriate leadership style will have implications for the work climate, work culture and high work motivation, and 3) the implementation of good teacher 
character will have implications for the character of students who were also good.

Based on the conclusions, it is suggested following suggestions: 1) the headmaster should apply the right leadership style for the development of a characterized teacher, 2) As a characterized teacher should conduct all of his duties and responsibilities as a teacher and educator and obey all rules and norms, especially in the institution she/he serves, and 3) the government in this case the education department that cover the education unit should conduct a continuous and structured guidance as well as motivation to the education stakeholders to increase character values that are running low in almost all levels.

\section{REFERENCES}

[1] Ali Mohammad, dkk, 2009, Ilmu dan Aplikasi Pendidikan, Jakarta: IMTIMA

[2] Asmani Jamal, 2009. Manajemen Pengelolaan dan Kepemimpinan pendidikan Profesional, Jogyakarta: Diva Press

[3] Aqib Zainal dan Sujak, 2012. Panduan dan Aplikasi Pendidikan Karakter, Bandung: Yrama Widya

[4] Danim Sudarwan, 2010. Kepemimpinan Pendidikan, Bandung: Alfabeta

[5] Direktorat Jenderal Pendidikan Dasar. 2011, Pendidikan Karakter Untuk Membangung Karakter Bangsa, Policy Brief Edisi 4 Juli, http://dikdas.kemdikbud.go.id/application/media/file /Policy\%20Brief\%20Ed isi\%204.pdf

[6] Fathoni Abdurrahmat, 2006. Organisasi dan Manajemen Sumber Daya Manusia, Jakarta : PT Rineka Cipta.

[7] Gunawan Heri, 2012. Pendidikan Karakter, Bandung: Alfabeta

[8] Husaini Usman, 2009. Manajemen Teori, Praktik dan Riset Pendidikan, Jakarta: Gramedia Pustaka Umum

[9] Ihsan Fuad, 2005. Dasar-dasar Kepemimpinan, Jakarta: Rineka Cipta

[10] Imran Ali dkk, 2003, Manajemen Pendidikan, Malang: Universitas Negeri Malang

[11] Indrafachrudi Soekarto, 2006. Bagaimana Memimpin Sekolah yang Efektif, Bogor: GI

[12] Kemendiknas, 2010. Pengembagan Pendidikan Budaya dan Karakter Bangsa, Jakarta: BPP

[13] ----------, 2010. Pedoman Pelaksanaan Pendidikan Karakter, Jakarta: BPP

[14] Koswara Deni dan Halimah, 2008. Seluk Beluk Profesi Guru, Bandung: Pribumi Mekar

[15] Kusmayadi Ismail, 2010. Kemahiran Interpersonal untuk Guru, Bandung: Pribumi Mekar
[16] Machali Imam, Kepemimpinan pendidikan dan pembangunan karakter, Yokyakarta: Pedagogia

[17] Makawimbang Jerry, 2012. Kepemimpinan Pendidikan yang Bermutu, Bandung: Alfabeta

[18] Maksudin, 2013. Pendidikan Karakter Nondikotomik, Jurnal Pendidikan Karakter, http://journal.uny.ac.id/index.php/jpka/article/view/1 435/1223

[19] Masaong Kadim, 2010. Supervisi Pembelajaran dan Pengembangan Kapasitas Guru, Bandung: Alfabeta

[20] Masaong Kadim dan Tilome Arfan, 2011. Kepemimpinan Berbasis Multiple Intelligence, Bandung: Alfabeta

[21] Mulyasa, 2009. Standar Kompetensi dan Sertifikasi Guru, Bandung: Rosda

[22] ---------, 2012. Manajemen dan Kepemimpinan Kepala Sekolah, Jakarta : Sinar Grafika Office

[23] Munir Abdullah, 2010. Spritual Teaching, Yokyakarta: Pustaka Insan Madani

[24] Peraturan Pemerintah No 53 tahun 2010 tentang Disiplin Pegawai Negeri Sipil

[25] Peraturan Pemerintah Nomor 74 Tahun 2008, tentang Guru

[26] Riduwan, 2012. Metode dan Teknik Menyusun Proposal Penelitian. Bandung: Alfabeta

[27] Rohiat, 2010. Manajemen Sekolah, Bandung: Refika Aditama

[28] Siagian Sondang, 2003. Filsafat Administrasi, Jakarta: Bumi Aksara

[29] Simamora, 2006. Manajemen Sumber Daya Manusia Edisi III, Jakarta: Bumi Aksara

[30] Soekarso - Agus Sosro - Iskandar Putong - Cecep Hidayat (2010), Teori Kepemimpinan, Jakarta: Mitra Wacana Media.

[31] Soetopo Hendyat, 2012. Perilaku Organisasi, Bandung: Rosda

[32] Sugiyono, 2012. Metode Penelitian Pendidikan, Bandung: Alfabeta

[33] Suhardan Dadang, 2010. Supervisi Profesional. Bandung: Alfabeta

[34] Sulhan Najib, 2010. Pembangunan Karakter Pada Anak, Surabaya: SIC

[35] Supriadi, 2002. Sejarah Pendidikan Teknik dan Kejuruan di Indonesia, Bandung: Alfabeta

[36] Sutrisno Edy, 2009. Manajemen Sumber Daya Manusia, Jakarta: Kencana

[37] Syafaruddin (2010), Kepemimpinan Pendidikan, Jakarta: Quantum Teaching

[38] Triatna cepi dan Kharisma, Risma, 2008. EQ Power: Panduan Meningkatkan Kecerdasan Emosional, Bandung: Citra Praya

[39] Thoha Mifta, 2010. Kepemimpinan dalam Manajemen, Jakarta: Rajawali Pers 
[40] Undang- Undang RI nomor 14 tahun 2005 tentang Guru dan Dosen

[41] Uno Hamzah, 2010. Profesi Kepedidikan. Jakarta: Bumi Aksara

[42]--------, 2012. Teori Motivasi dan Pengukurannya, Jakarta: Bumi Aksara

[43] Wahab dan Umiarso, 2011. Kepemimpinan Pendidikan dan Kecerdasan Spiritual, Jogjakarta: Ar-ruz Media

[44] Wahyudi (2009), Kepemimpinan Kepala Sekolah dalam Organisasi Pembelajaran, Bandung: Alfabeta

[45] Wardhana Yana. 2007. Manajemen Pendidikan untuk Meningkatkan Daya Saing Bangsa, Bandung: Pribumi Mekar 